\title{
THE IMPACT OF SOCIO-ECONOMIC AND DEMOGRAPHIC DETERMINANTS ON SELF-PERCEIVED HEALTH
}

\author{
Pavla Jindrová', Viera Labudová2
}

\footnotetext{
1 University of Pardubice, Faculty of Economics and Administration, Institute of Mathematics and Quantitative Methods, Czech Republic, ORCID: 0000-0002-7995-1989, pavla.jindrova@upce.cz;

2 University of Economics in Bratislava, Faculty of Economics Informatics, Department of Statistics, Slovakia, ORCID: 0000-0003-2022-1751, viera.labudova@euba.sk.
}

\begin{abstract}
This article presents an overview of the self-reported health status of the population of the European Union Member States (EU-28) in the year 2018 based on Eurostat data. The selfreported health status of the inhabitants of the Slovak Republic has been analyzed in more detail with regard to the availability of individual data of the survey results from the European Statistics of Income and Living Condition (EU-SILC). The aim of the article is to analyse the relationship between social and demographic characteristics and the self-perceived health of the population in the EU-28 countries and their comparison as well as a comparison with the results found in the Slovak Republic. The characteristics gender, age, educational level, income, employment, and place of residence have been considered as the determinants of the self-reported health status. The obtained results of self-reported health status by selected demographics and social indicators in the European Union Member States have been compared in visual form using tables and graphs. For assessment of impact selected socio-economic and demographic characteristics on the selfperceived health by inhabitants in the Slovak Republic has been used the logistic regression model based on data extracted from the EU SILC 2016 cross-sectional component provided by the Statistical Office of the Slovak Republic. The obtained results can provide valuable information for health protection policy in EU countries and especially in the Slovak Republic. It could also be used to compare self-reported health status in the EU countries and the health status established based on the official health data published by European institutions.
\end{abstract}

Keywords: Health status, self-perceived health, health determinants, logistic regression.

JEL Classification: 114, C25, C31, C83.

APA Style Citation: Jindrová, P., \& Labudová, V. (2020). The Impact of Socio-economic and Demographic Determinants on Self-perceived Health. E\&M Economics and Management, 23(4), 68-88. https://doi.org/10.15240/tul/001/2020-4-005

\section{Introduction}

The World Health Organisation (WHO, 1946) defines health as 'a state of complete physical, mental and social well-being and not merely the absence of disease or infirmity'. Good health is not only of value to the individual as a major determinant of quality of life, well-being and social participation, but it also contributes to general social and economic growth.

Good health is a key aspect of people's well-being and enhances opportunities to participate in the labour market and to benefit from economic and employment growth. People with poor physical or mental health are less likely to work and more likely to be unemployed than people in better health. The relationship also works the other way around: people with higher level of education and higher income tend to be in better health and live longer than those with lower level of education and income (OECD, 2015).

Indicators on health status are given high importance in EU health policies. The monitoring of health status of populations 
was included in the overarching EU strategy 'Together for Health: A Strategic Approach for the EU 2008-2013' (European Commission, 2007) and in the 'Investing in health' working document (European Commission, 2013).

Almost five years have passed since the 2030 Agenda for Sustainable Development and its Sustainable Development Goals (SDGs) were adopted by all 193 Member States of the United Nations. Health is a core dimension of the SDGs; goal 3 aims to 'ensure healthy lives and promote wellbeing for all at all ages' (UN, 2015). To measure progress on the SDGs, these existing efforts will need to be leveraged, particularly those that provide comparable assessments of health outcomes and risks across countries and over time. An important goal of this document is also goal 10 aims to 'reduce inequality within and among countries'. The SDGs aims to strengthen the capacities of Member States to achieve better, more equitable, sustainable health and well-being for all at all ages.

The health status of a population cannot be captured by a single metric and it is determined by many factors outside of the health systems. Health status is usually described by life expectancy, healthy life expectancy, and the burden of disease approximated by death rates by causes of mortality. These are broad indicators that are influenced by many factors besides the provision of health services, namely a wide range of environmental and socio-economic variables, such as air pollution, education, income, working conditions, and lifestyle (European Commission, 2016).

Another useful complementary measure is self-perceived health, in which people provided an assessment of their own general health. Despite its subjective nature, this indicator provides additional insight into the well-being of individuals and is found to be a good predictor of future health care use (OECD/EU, 2019).

The EU Survey on Income and Living Conditions (EU-SILC), which is carried out annually, provides some information on health inequalities between social groups. It is based on a total sample of over 400,000 adults living in households and provides a mixture of crosssectional and longitudinal data from all EU Member States. The sample does not include people living in care homes or other institutions. The survey includes questions, enabling an assessment to be made of income, educational level, material deprivation, self-perceived health and self-perceived limitations in daily activities (Eurostat, 2010).

Self-perceived health expresses a subjective assessment by the respondent of his/her health. Indicators based on this concept can be used to evaluate the general health status, health inequalities and health care need at the population level. Despite their subjective nature, the statistics are considered to be relevant and reliable estimators of the health status of populations as well as good predictors of health care needs, and they are useful for trend analysis and for measuring socio-economic disparities. According to several publications (Bound, 1991; Pacáková \& Kopecká, 2018b), the results of self-reported health are very reliable and comparable with the results obtained by the official health indicators.

The concept of self-perceived health is operationalized by a question on how a person perceives his/her health, in general, using one of the answer categories 1 . very good, 2. good, 3. fair, 4. bad, 5. very bad. The notion is restricted to an assessment coming from the individual and not from anyone else, whether an interviewer, healthcare professional or relative (European Commission, 2017).

In this article, we will focus on the selfperceived variants 'very good' or 'good' to assess the impact of socio-economic and demographic determinants on health in EU-28 members and differences between countries. We also continue with the comparison of good self-perceived health in the Slovak Republic within the EU countries and we try to identify which groups of respondents most contributed to that.

\section{Theoretical Background}

Traditionally the health of populations has been measured in mortality, morbidity, life expectancy, healthy life years, consultation rates and so on. These measures, however, are acknowledged to have many limitations. An individual's perception of his or her health status is coming to be seen as an essential adjunct to the traditional indicators in the assessment of health needs. The current recognition of the importance of perceived health status as a predictor of the need for, and utilization of, health services has led to attempts to produce indicators that assess subjective rather than objective health problems (Hunt et al., 1980). 
The subjective health assessment reflects a person's integrated perception of health, including its biological, psychological and social dimensions. Therefore, subjective assessments of general health could be even more sensitive in health monitoring than external measures of health. In recent studies, subjective assessment of health has also been found to be highly correlated with the results of its objective assessment and health status indices (Bound, 1991; Pacáková \& Kopecká, 2018b). The significant similarity between selfreported and objectively determined health status in European countries, measured by the Spearman rank correlation coefficient equal to 0.8223 , is presented in the article (Pacáková \& Kopecká, 2018b).

A growing body of evidence has demonstrated that an individual's health also depends on factors that go beyond the biological endowment and medical care received. In particular, non-medical determinants related to lifestyle choices are important. These include major risk factors such as smoking, alcohol and an unhealthy diet, and conversely healthseeking activities such as physical activity (GBD 2015 Risk Factors Collaborators, 2016). But broader social determinants of health also matter. Income, education, working, and living conditions are all also important factors.

There have been a number of major studies of the social determinants of health, which have demonstrated a clear link between socioeconomic background (such as income or occupation) and health (Department of Health and Social Security, 1980; Marmot et al., 2010). The Marmot Review (Marmot et al., 2010) presents a robust and well-evidenced foundation for national and local action to address health inequalities through concerted action. It proposes an evidence based strategy to address the social determinants of health, the conditions in which people are born, grow, live, work and age and which can lead to health inequalities.

A range of studies using aggregated data highlight the contribution of socio-economic factors to health (Bambra et al., 2010; Marmot \& Wilkinson, 2006; Pickett \& Wilkinson, 2015). The Spirit Level (Wilkinson \& Pickett, 2009) presented data and argument from a wide range of studies and the main focus of the book has been the analysis of the correlation between income inequality and health and social problems.
Many of the early studies in this field used only correlation analysis of aggregate-level cross-sectional data. There is considerable debate about the nature and size of any causal link between income inequality and health and social problems. The paper by Pickett and Wilkinson (2015) assessed whether wider income differences play a causal role leading to worse health. This paper contains a literature review within an epidemiological causal framework and authors inferred the likelihood of a causal relationship between income inequality and health by considering the evidence as a whole.

More recent studies have moved away from simple correlation analysis to investigate whether social inequality causes health problems. Several studies have analysed the association between health and socio-economic status based on data of self-perceived health. A positive relationship between self-perceived health and socio-economic status is widely documented across many societies and periods. Below are some examples of these studies and their basic results.

The objective of the study by AlvarezGalvez et al. (2013) is to determine the effect of three socio-economic determinants (income, education and occupational status) on self-rated health in 29 countries according to findings in European Social Surveys (20022008), in order to study how socio-economic inequalities can vary our subjective state of health. The Ordered Logistic Regression (OLR) model was performed and in line with previous studies, the results point out the relevance of socio-economic factors in explaining the differences in individuals' states of health. This study indicates the relevance of education in preserving a good general state of health during the period 2002-2008. The study by AlvarezGalvez et al. (2014) is aimed at comparing the effect of different measures of socio-economic status on self-rated health throughout European welfare state regimes during the period 20022008 , in order to study how diverse socioeconomic inequalities can vary our health over time. The main finding to be highlighted is that the importance of education-related inequalities surpasses differences in income and occupational status, especially in southern and eastern countries. The Alvarez-Galvez's (2016) study uses an additive Bayesian Networks model to explain the interrelationships between 
health and socio-economic determinants and provides a general framework to describe and understand the complex association between socio-economic determinants and health.

The aim of the study by Kaleta et al. (2008) was to evaluate the association between employment status and self-rated health in the population of Poland. The study was performed in the randomly selected population of individuals aged 25-64 years. Logistic regression was used to estimate odds ratios and $95 \%$ confidence intervals as well as to control the effects of employment status and self-rated health. Self-health assessment is related to a number of factors, including unemployment, low education or income that increase the risk of poor health. These results emphasize the potential health consequences of unemployment and material circumstances in Poland. The logistic regression model was applied to assess the factors influencing the self-perception of health also in paper (Kaleta et al., 2009).

The relationship between unemployment and self-assessed health using the European Community Household Panel for Finland over the period 1996-2001 examines paper by Böckerman and IImakunnas (2009). The results show that the event of becoming unemployed does not matter as such for self-assessed health. The health status of those that end up being unemployed is lower than that of the continually employed. The paper by Johansson et al. (2020) examines the relationship between unemployment and health using both subjective and biometric information on health status. These results indicate a substantial discrepancy between self-reported health and health as measured by biomarkers.

Nummela (2007) examines associations between self-rated health and three indicators of social-economic situation (education, disposable household income, adequacy of income) and three types of communities (urban, densely or sparsely populated rural areas) among ageing men and women in the Province of Päijät-Häme, Southern Finland. After adjusting for other factors, adequacy of income showed the strongest (positive) association with self-rated health in urban areas in all age groups.

Analysis of inequalities in suffering health limitations in daily activity by using the EUSILC longitudinal data for the waves 2005 to 2007 in 20 European Member States for which data was available presents the paper by Hernández-Quevedo et al. (2010). The regression analysis shows that demographic factors such as age and gender pre-determine an individual to report health limitations. Besides, factors such as activity status, education, and different indicators of social exclusion are highly associated with perceiving health limitations in daily activity, as showed by the results of the regression analysis as well as the decomposition analysis.

More detailed results of the analysis of an indicator of suffering health limitations in daily activity for 20 European Member States based EU-SILC data present working papers Eurostat (2010). In order to measure inequalities in health limitations, the concentration index is used. Besides includes a regression analysis where pooled probit models are used to disentangle the associations between perceiving health limitations in daily activity and different demographic and socioeconomic factors included in the database. There is evidence of income-related inequalities in health for all the countries analyzed, although they present a heterogeneous pattern over time. The regression analysis and decomposition approach show that demographic factors such as age and gender are important factors and contribute to the pro-poor inequalities in most countries. Social exclusion factors such as the ability to make ends meet and to afford a week holiday at year, together with activity status, education and income, are highly associated with perceiving health limitations in daily activity.

Szeles (2018) examines the determinants of self-perceived health in the EU-27 area in order to find whether a common set of governmental policies could improve the self-perceived health and whether this positive effect would remain positive and significant on other measures of the quality of life as well as across the quintiles of the income distribution. A number of panel regression models are applied to comparatively examine self-perceived health together with other measures of health status and quality of life, based on Eurostat data from 2003 to 2012. The empirical results of the paper could provide useful insights for the European health policy and other common actions and policies in the field of the quality of life.

In various fields of research, self-perceived health has been defined and analyzed as 
a significant measure of the health-related quality of life, and also as a predictor of health status. In line with the Sustainable Development Goals (United Nations, 2015), the results of analyses of socio-economic and demographic determinants on self-perceived health approach provide a value-based and practical framework for public health action.

\section{Data and Research Methodology}

We used two types of data to achieve the set of goals of the article. Aggregate data for EU-28 countries focusing on Self-perceived health statistics come from online-published module European Union - facts and figures (2020) providing recent statistics on health in the European Union (EU). The source of this data is European Union Statistics on Income and Living Conditions (EU-SILC). We focused on data from year 2018 of respondents aged 16 and over. Based on this data, we compared the prevalence of very good or good self-perceived health across European Union countries and investigated which survey characteristics contributed to differences in prevalence estimates. We mainly used graphical methods of descriptive statistics. This made it possible to present the results of the comparison according to selected characteristics demographic (gender, age), social (educational level, labour status), environmental (urbanization), and economic (income) as well as comparisons between EU-28 countries. The results of these comparisons are presented in Chapter 3.

The individual-level data of respondents extracted from EU SILC 2016 cross-sectional component provided by the Statistical Office of the Slovak Republic (EU SILC 2016, UDB 27/04/2017) have been used to analyse the relationship between characteristics of individuals and self-perceived health in the Slovak Republic. To achieve this goal a logistic regression model was used using SAS Enterprise Guide 5.1.

Variable General Health with answer categories 1. very good, 2. good, 3. fair, 4. bad, 5 . very bad in EU SILC is a measure of self-perceived health (SPH) by the selected respondents aged 16 and over. For logistic regression model has been created a binary dependent variable which equals ' 1 ' if individuals self-perceived health as 'very good' or 'good', or equals as ' 0 ' otherwise. This dichotomy is commonly used by others investigating SPH (Manderbacka et al., 1999) and helps account for imbalances resulting from low numbers of respondents in the extreme lower ends of the scale (i.e. those reporting 'very bad'). The outcome of interest for the study is 'good health' (categories 'very good' or 'good'), so the dichotomy variable equals value ' 1 '.

As explanatory variables have been included these demographic or socio-economic indicators:

- marital status (PB190) (three dummies indicating whether the individual is never married, married or widowed, divorced is the reference category);

- age (PX010) (age was grouped in four categories - dummy variables: between 16 and less than 25 , between 25 and less than 45 , between 45 and less than 65 and above 65 years old; the category above 65 years old is the reference category (in our analysis we included the logarithm of variable age too);

- the highest level of education attained based on the ISCED (PE040) (we included two dummy indicators: secondary (upper secondary education - not further specified and post-secondary non-tertiary education - not further specified) and tertiary (short cycle tertiary, bachelor or equivalent, master or equivalent, and doctorate or equivalent); the reference category is primary (less than primary education, primary education, and lower secondary education);

- self-defined current economic status (PL031) (then dummy variables indicating whether the individual is in full-time employment, part-time employment, self-employed working full-time, selfemployed working part-time, unemployed, pupil, student, further training, unpaid work experience, retirement or in early retirement or has given up business, permanently disabled or/and unfit to work, in the compulsory military or community service, fulfilling domestic tasks and care responsibilities or other inactive person which is our reference category);

- basic activity status (RB210) (three dummy variables indicating whether the individual is at work, unemployed and other inactive person; in retirement or early retirement or has given up business is our reference category); 
- most frequent activity status (PX050) (three dummy variables indicating whether the individual is at work, unemployed and other inactive person; in retirement or early retirement or has given up business is our reference category);

- poverty status (ARPT60i) (a dummy indicating whether the household's equalized disposable income (after social transfer) is above the at-risk-of-poverty threshold, which is set at $60 \%$ of the national median equalized disposable income after social transfers);

- severely material deprivation (at least 4 out of 9 deprivation items) (SEV_DEP) (a dummy indicating whether the household is not deprived) (Severely Materially Deprived (SEV_DEP) are those individuals being in the state of enforced inability to pay for at least four of the nine following terms: 1. to pay their rent, mortgage or utility bills, 2. to keep their home adequately warm, 3. to face unexpected expenses, 4. to eat meat or proteins regularly, 5 . to go on holiday, 6 . a television set, 7 . a washing machine, 8. a car, 9. a telephone) (European Commission, 2017));

- low work intensity of the household (LWI) (a dummy indicating whether the household's work intensity is not very low), (The household with very low work intensity is defined as a household where the members of working age worked less than $20 \%$ of their total potential during the previous 12 months. The work intensity of a household is the ratio of the total number of months that all working-age household members have worked during the income reference year and the total number of months the same household members theoretically could have worked in the same period. A working-age person is a person aged 18-59 years, with the exclusion of students in the age group between 18 and 24 years.);

- equalized household disposable income (EQ_INC20) (four dummy variables indicating the income quintile; the first quintile of equalized income is the reference category), we included the logarithm of this equalized household disposable income too (Equalised disposable income (EQ INC) is the total income of a household that is available for spending or saving, divided by the number of household members converted into equalized adults; household members are equalized or made equivalent by the following so-called modified OECD equivalence scale.);

- region (DB040) (three dummy variables refer to the region of the residence of the household at the date of interview: SK01/ Bratislava Region, SK02/Western Slovakia and SK03/Central Slovakia; SK04/Eastern Slovakia is our reference category);

- degree of urbanization (two dummy variables: densely populated area (at least 500 inhabitants $/ \mathrm{km}^{2}$ ) and intermediate area (between 100 and 499 inhabitants/ $\mathrm{km}^{2}$ ); thinly-populated area (less than 100 inhabitants $/ \mathrm{km}^{2}$ ) is the reference category);

- NUTS 3 (seven dummy variables refer to the region of the residence of the household at the date of interview: Bratislava Region, Trnava Region, Trenčín Region, Nitra Region, Žilina Region, Banská Bystrica Region and Košice Region; Prešov Region is our reference category).

In order to estimate the dependent effects of demographic and socio-economic determinants on 'very good' or 'good' self-perceived health, multivariable logistic regression model (Stankovičová \& Vojtková, 2007; Hosmer \& Lemeshow, 2004) have been used. To obtain maximum likelihood estimators of parameters of the model the Newton-Raphson algorithm is generally used (Allison, 2012). Odds ratios are used to compare the relative odds of the occurrence of the outcome of interest (e.g. good self-perceived health status), given exposure to the explanatory variable of interest. The odds ratio can also be used to determine whether a particular variable is a risk factor for a particular outcome and to compare the magnitude of various risk factors for that outcome.

The logistic regression model often has been used for describing the relationship between the occurrence of an event/characteristic/ choice of individuals and explanatory factors, for example in Prokop et al. (2018), Karasová et al. (2019), Alvarez-Galvez et al. (2013) and Kaleta et al. (2008).

\section{Results of Self-reported Health Status in EU-28}

This chapter contains the results of an analysis to assess how demographic and socioeconomic characteristics affect self-perceived 


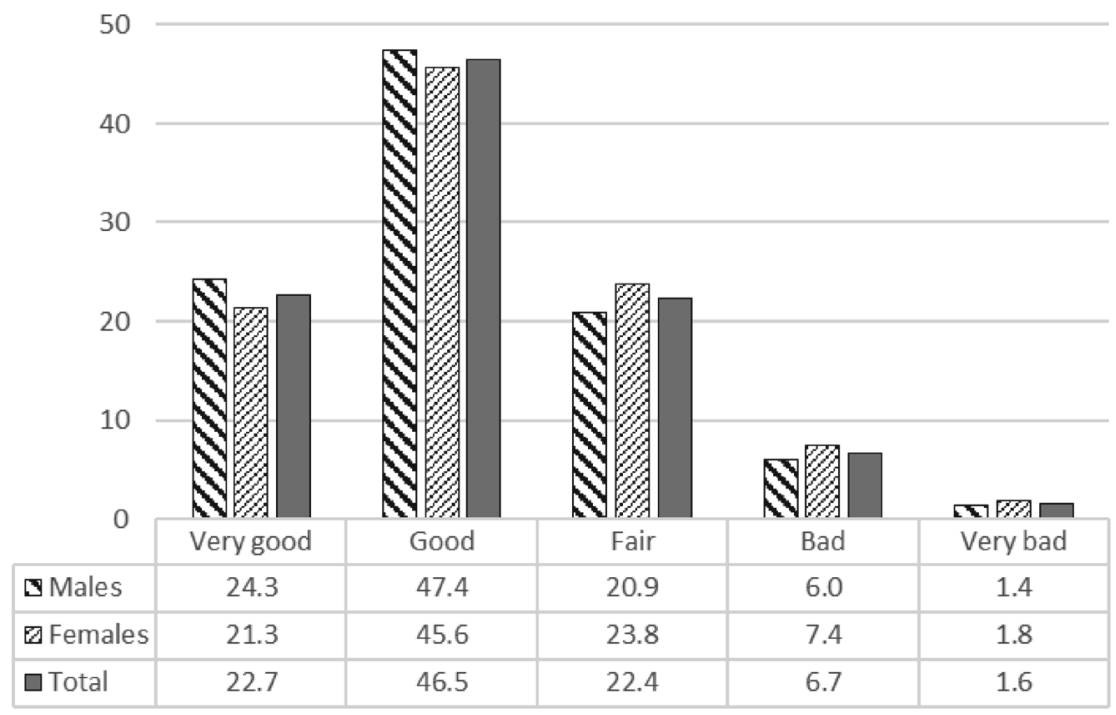

Source: own based on Eurostat

\section{Fig. 2: Comparison of share of persons aged 16 and over with very good or good self-perceived health in EU-28 countries, by gender, 2018}

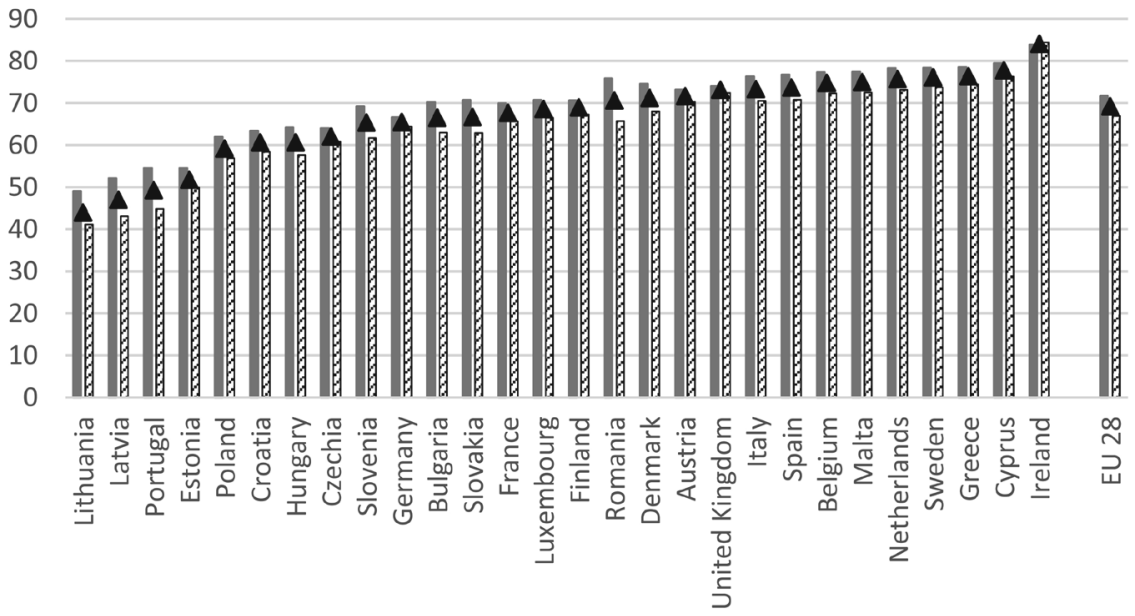

Males $\square$ Females $\boldsymbol{\Delta}$ Total 
health of persons aged 16 and over in European Union countries. The results are presented in the form of tables and graphs.

By Fig. 1 the most respondents in EU-28 opted for variant 'good', $69.2 \%$ of the population aged 16 and over perceived their health as 'very good' or 'good', while $22.4 \%$ perceived it as 'fair' and $8.3 \%$ as 'bad' or 'very bad'. The gender difference in reporting of health is not very large, but more women than men report worse health and conversely, more men than women claim to be in good or very good health.

Further, we will focus on the self-perceived health variants 'very good' or 'good' in European Union member countries. Fig. 2 shows the EU28 countries arranged in ascending order by the proportion of respondents in 'very good' or 'good' answer categories on self-perceived health by gender. The proportion of people reporting 'very good' or 'good' health varies from $44 \%$ in Lithuania to $84.1 \%$ in Ireland. In 2016, men were more likely to rate their health as 'very good' or 'good' than women in all EU28 countries. Across the EU Member States, the Slovak Republic in this arrangement is ranked 13th, the share of people who perceived their health as 'very good' or 'good' was $66.7 \%$, which is the highest share of all post-socialist countries, except Romania. This is a rather surprising result that is contrary to several published comparisons of health status in
European countries, for example Olsen and Dahl (2007), OECD/EU (2018), Pacáková and Kopecká (2018a), Pacáková and Jindrová (2019), Wilkins et al. (2017).

The time series in Fig. 3 confirm that the good outcome of self-perceived health in the Slovak Republic in 2016 compared to other selected countries EU was not accidental. For comparing the EU countries bordering Slovakia are selected, as well as countries with the highest or lowest value of 'very good' or 'good' self-perceived health.

A strong association between self-perceived health and age group is apparent from Fig. 4. To highlight the age differences in perceived health has been was dichotomized into 'good health' ('very good' or 'good' variants) or 'bad health' for three other variants. Younger people seem to perceive their health as 'very good' or 'good'. $91.5 \%$ of respondents aged 16-24 reported 'good' or 'very good' health, while for increasing ages this percentage decreases to about $72.4 \%$ of respondents aged $45-54$ to only $41.9 \%$ of respondents aged $65+$. On the contrary, exponentially increased occurrence of the variant 'bad', from $8.5 \%$ at age $16-24$ to $58.1 \%$ at age $65+$.

The other significant factor for 'very good' or 'good' self-perceived health in EU-28 countries is education level (Fig. 5). The health gap between educational attainment levels is

\section{Fig. 3: The proportion of persons aged 16 and over with very good or good self-perceived health in EU selected countries in time period 2005-2018}

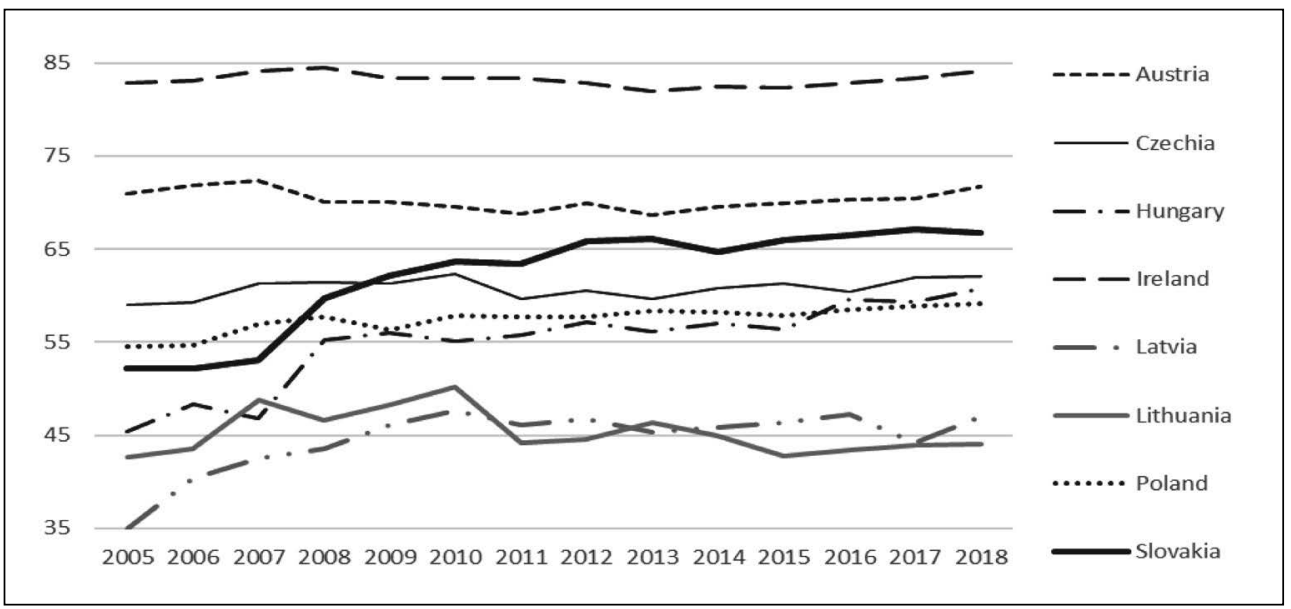




\section{Economics}

Fig. 4:

Self-perceived health of persons aged 16 and over with good or bad self-perceived health, by age, EU-28, 2018

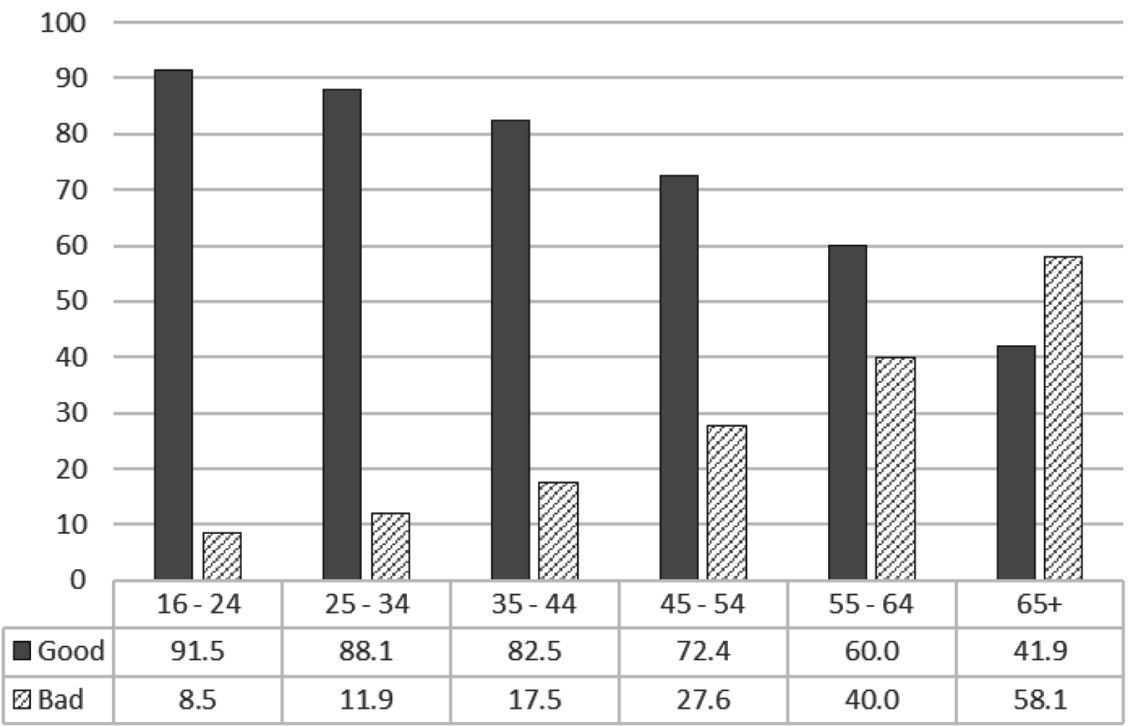

Source: own based on Eurostat

Fig. 5:

Share of persons aged 16 and over with very good or good self-perceived health, by educational attainment level, EU-28, 2018

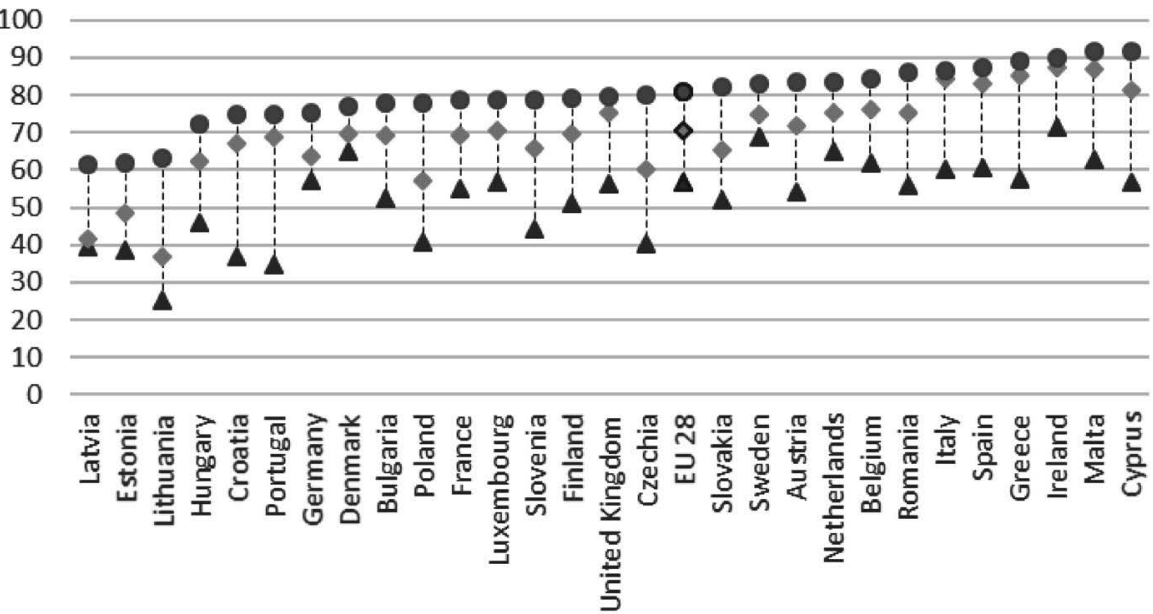

$\Delta$ Primary education $\diamond$ Secundary education Tertiary education 

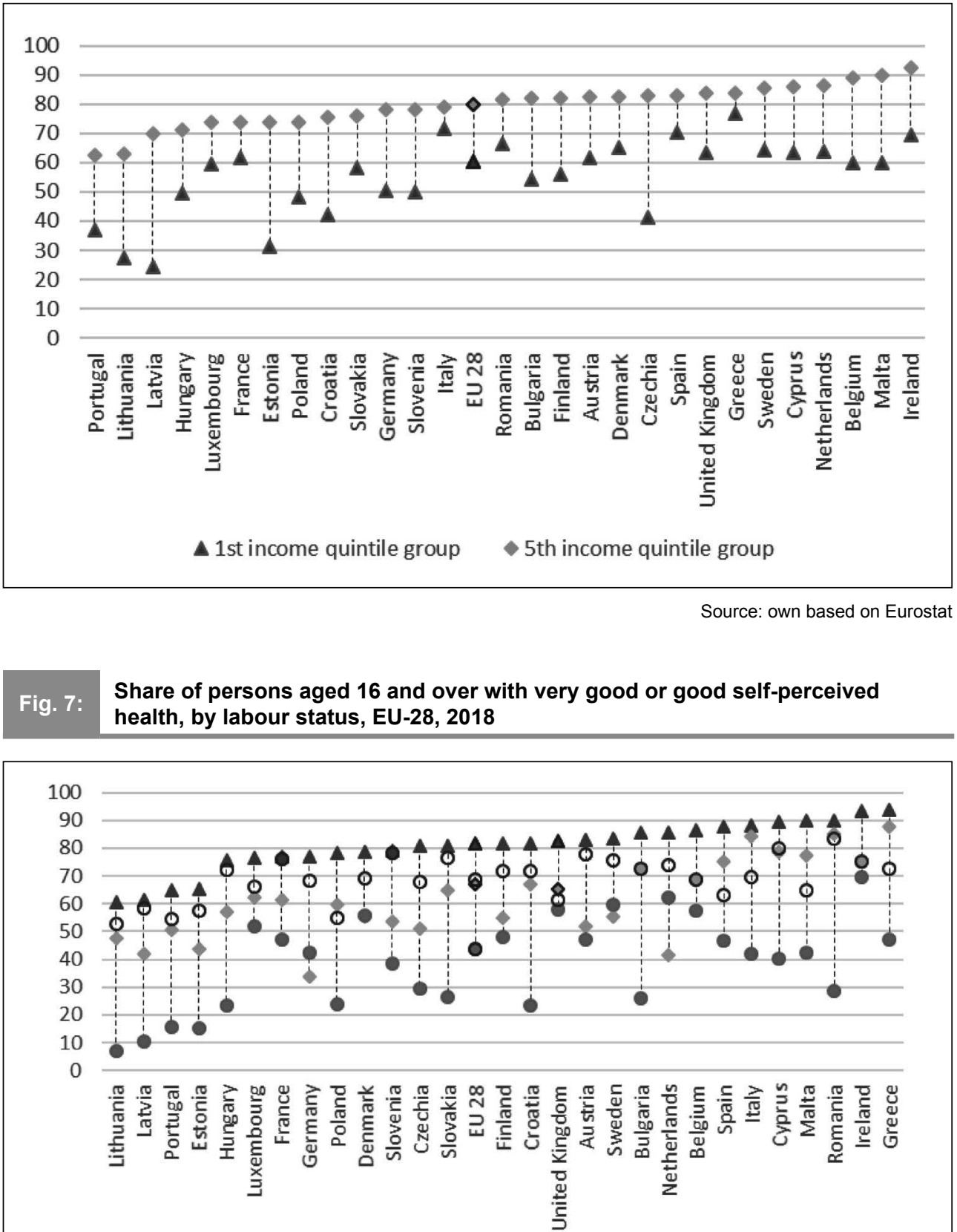

$\Delta$ Employees $\diamond$ Unemployed persons - Retired persons O Other inactive persons 
apparent in all EU Member States. The largest gap in the share of the population reporting 'very good' or 'good' health between those with the highest and the lowest educational attainment levels was observed in Portugal, Czechia and Lithuania as well as Croatia and Poland, the smallest gap was observed in Denmark, Sweden and Germany as well as the Netherlands and Ireland. In the Slovak Republic the share of the population reporting 'very good' or 'good' health was $82.1 \%$ in 'Tertiary education' level and $51.8 \%$ in 'Primary education' level.

There are also disparities in self-reported health across different socio-economic groups in EU Member States (Fig. 6). These disparities are particularly large in Baltic countries (Estonia, Latvia and Lithuania) and in Czechia. In these countries people in the highest income group report to be in 'good' health from $62.9 \%$ in Lithuania to $83 \%$ in Czechia, but this proportion goes down to about one-third only for people in the lowest income group.

The relationship between self-perceived health and labour (activity) status in EU-28 countries can be observed in Fig. 7. There are disparities for employees - 'very good' or 'good' self-perceived health is from $60.5 \%$ in Lithuania to $93.9 \%$ in Greece. And disparities for retired persons are bigger - from $7.2 \%$ in Lithuania to $69.4 \%$ in Ireland.

The relationship between self-perceived health and degree of urbanization in EU-28 countries can be observed in Fig. 8. These disparities are particularly large in Lithuania, Portugal and Bulgaria.

\section{Results of Self-reported Health Status in the Slovak Republic}

This chapter contains the results of an analysis to assess how demographic and socioeconomic characteristics affect self-perceived health of persons aged 16 and over in the Slovak Republic.

Fig. 9 shows the proportion of respondents in each of the five answer categories on selfperceived health, by gender. The gender difference in reporting of health is significant $(p<0.0001)$. More women than men report worse health (fair/bad/very bad), and conversely, more men than women claim to be in 'very good' or 'good' health.

Based on the results of other studies (Alvarez-Galvez et al., 2013; Croezen et

\section{Fig. 8: Share of persons aged 16 and over with very good or good self-perceived health, by degree of urbanization, EU-28, 2018}

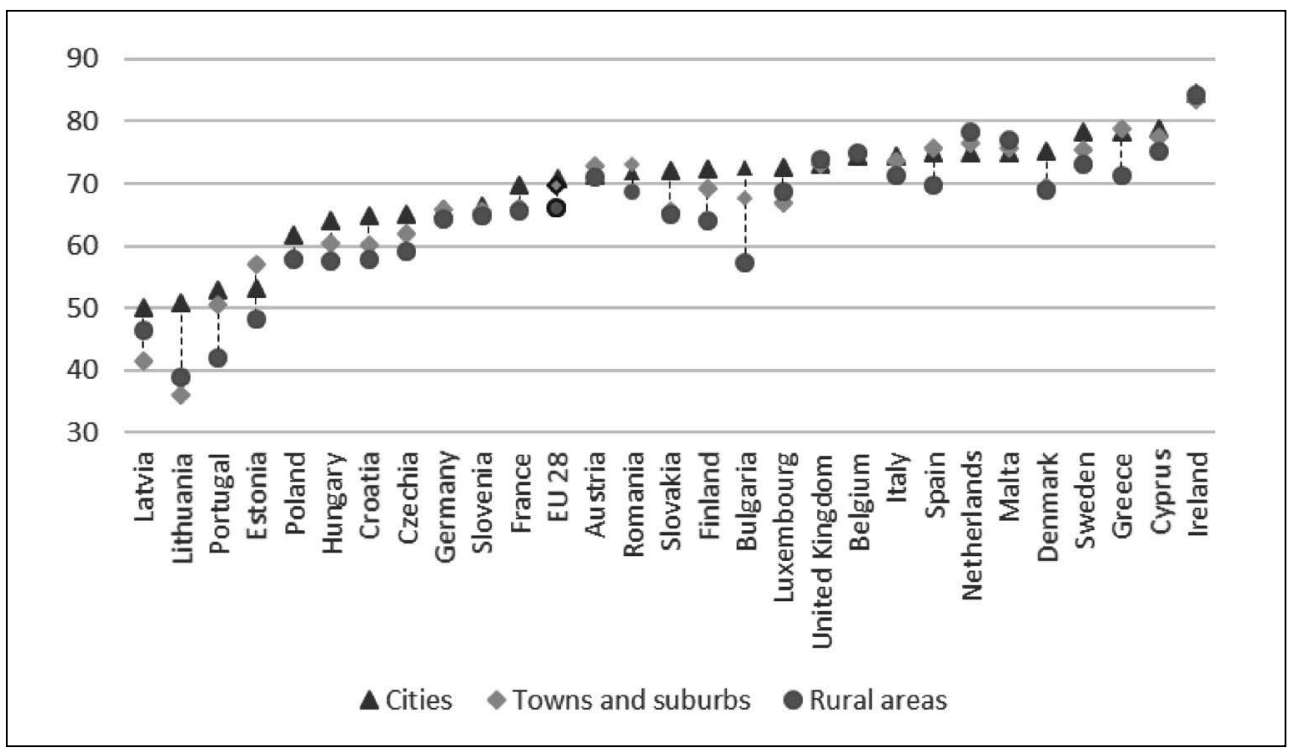

Source: own based on Eurostat 


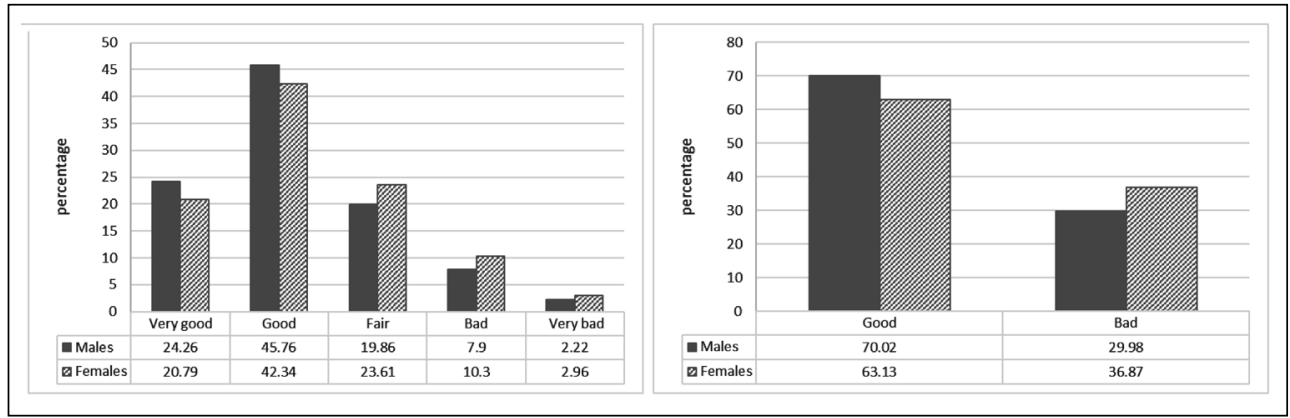

Source: own based on Statistical Office of the Slovak Republic, EU SILC 2016, UDB 27/04/2017

al., 2016; Eikemo et al., 2008; Kaleta et al., 2009; Pärna \& Ringmets, 2010; Robards et al., 2012), we were interested in whether the self-perceived health inequalities of the Slovak population aged 16 and over are determined by other demographic and socio-economic indicators than gender.

The relationship between 'good' selfperceived health status and demographic and socio-economic variables simultaneously, we investigated through logistic regression analysis. All variables were included in a stepwise elimination procedure with a $p$-value to exit set at $>0.05$. The following variables were selected for this model: marital status, age, the highest level of education, activity status, severe material deprivation, equivalised household disposable income, region NUTS3 and degree of urbanization (Tab. 1).

The quality of the logistic models was evaluated with AIC - Akaike Information Criterion and SC - Schwarz Bayesian

\section{Fig. 10: Self-perceived health by age}

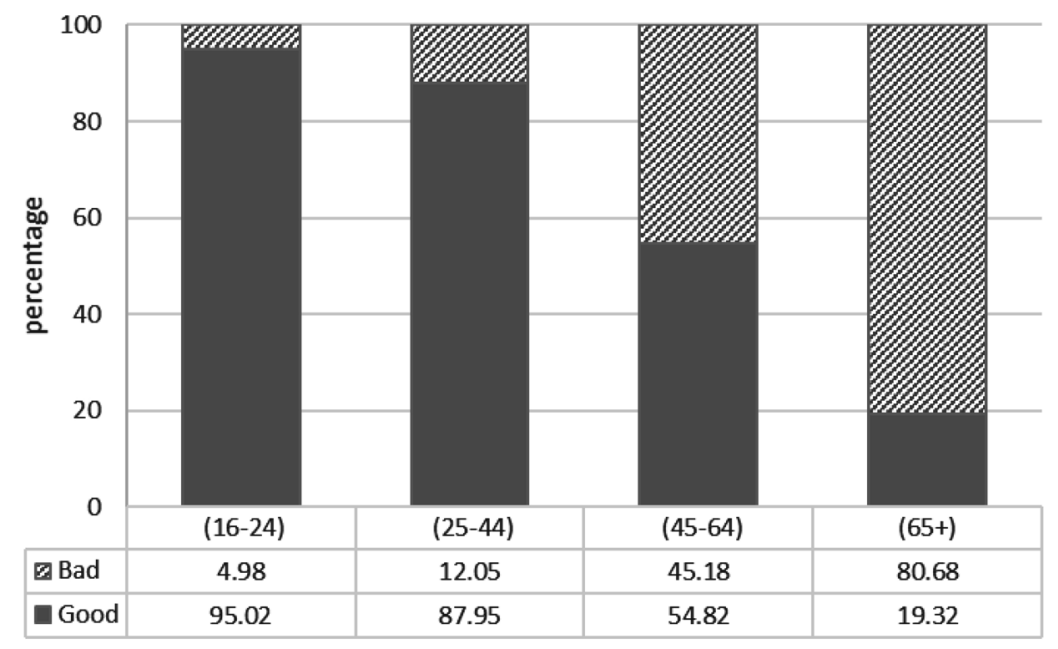

Source: based on Statistical Office of the Slovak Republic, EU SILC 2016, UDB 27/04/2017 
information criterion (Stankovičová \& Vojtková, 2007). We have built models for men and women separately in order to highlight the differences between them. Bivariate analyses of the independent variables categories with SPH categories was performed using chi-squared statistics. Tab. 1 presents distribution (weighted percentage) of the selected demographics and socioeconomic variables across SPH categories, the $p$-values of chi-squared tests and the measures of association (Cramer's V, Lambda asymmetric SPH|explanatory variable) and Uncertainty Coefficient SPH|explanatory variable).

Self-perceived health has a distinct age pattern as fewer people tended to rate their health as being 'very good' or 'good' in higher age groups than in lower age groups, while the share reporting bad or very bad health increased with age. $80.68 \%$ of respondents aged 65+ reported bad health, while for respondents aged 16-24 this percentage was about $5 \%$ and of the 25-44 years old respondents about $12 \%$ reported bad health (Fig. 10, Tab. 1). In all age groups, men were more likely than women to describe their health as very good or good. However, the only age group at which the difference was significant was 65+. Conversely, a higher percentage of women than men described their health as fair/ $\mathrm{bad} / \mathrm{very}$ bad (Tab. 1). The findings for the age group 65+ may partly result from individuals assessing their health in relation to social roles. If people feel they are not fulfilling these roles, their health perceptions may be more negative (Shields \& Shooshtari, 2001).

A strong determinant of good self-perceived health is family status (Cramer's $V=0.3911$ ) (Fig. 11). The most of never married people rate their health as 'good' $(87.21 \%)$, which is in contrast to the widowed, among whom $80.60 \%$ rated their health as 'bad'. For women, this is even higher (81.23\%) (Tab. 1).

Clear differences appear when looking at the relationship between self-perceived health and educational attainment level. The impact of education on SPH is particularly evident in those who have completed tertiary education. In this group, the proportion of people who selfperceived health as 'good' is $83.19 \%$, which is about 1.62 times higher than the prevalence of 'good' and 'very good' assessment of health status in a group of people who have completed primary education. The impact of the SPH level

\section{Fig. 11: Self-perceived health by marital status}

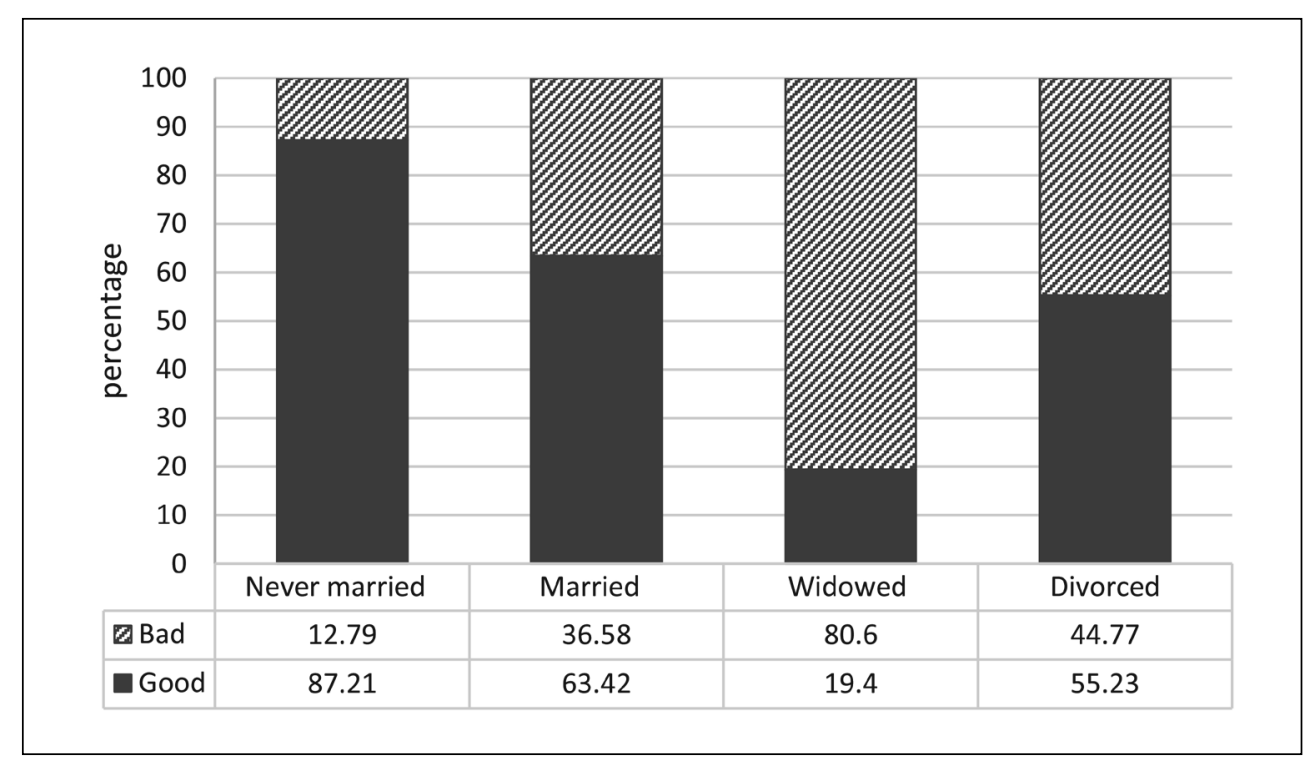

Source: based on Statistical Office of the Slovak Republic, EU SILC 2016, UDB 27/04/2017 
of education is stronger in women (Cramer's $\mathrm{V}=0.27$ ) than in men (Cramer's $\mathrm{V}=0.12$ ). Women who have completed primary education only assess their health status as being 'bad', while men tend to have a good assessment of their health no matter what their education is.

Strongly related to the reporting of SPH status is activity status (Cramer's $\mathrm{V}=0.5160$; Uncertainty Coeff. $C \mid R=0.2041)$. The highest prevalence of poor health assessment is among retirees, of which up to $76.41 \%$ assess their health status as being 'bad'.

For the income level, the higher the income is, the smaller proportion of respondents reporting health as 'bad'. The proportion of $63.88 \%$ of the population in the first income quintile group and $57.41 \%$ in the second income quintile group perceived their health as 'very good' or 'good', compared with $79.45 \%$ in the fifth income quintile group.

\section{Tab. 1: \\ Self-perceived health according to sociodemographic characteristics of respondents - Part 1}

\begin{tabular}{|c|c|c|c|}
\hline \multirow[b]{2}{*}{ Explanatory variables } & \multicolumn{2}{|c|}{ SPH status } & \multirow{2}{*}{$\begin{array}{c}\text { Cramer's V; Lambda C|R; } \\
\text { Chi-squared (p-value); } \\
\text { Uncertainty Coeff. C|R }\end{array}$} \\
\hline & $\begin{array}{c}0 \\
(\%)\end{array}$ & $\begin{array}{c}1 \\
(\%)\end{array}$ & \\
\hline \multicolumn{3}{|l|}{ Gender } & \multirow{3}{*}{$\begin{array}{l}\text { Cramer's V = 0.0729; } \\
\text { Lambda C|R = } 0.0000 ; \\
\text { Chi-squared ( } p \text {-value) }<0.0001 \\
\text { Uncertainty Coeff. C|R }=0.0042\end{array}$} \\
\hline Male & 29.98 & 70.02 & \\
\hline Female & 36.87 & 63.13 & \\
\hline \multicolumn{3}{|l|}{ Age } & \multirow{5}{*}{$\begin{array}{l}\text { Cramer's V = 0.5275; } \\
\text { Lambda C|R = 0.2392; } \\
\text { Chi-squared (p-value) <0.0001; } \\
\text { Uncertainty Coeff. C|R = } 0.2371\end{array}$} \\
\hline$(16-24)$ & 4.39 & 95.61 & \\
\hline$(25-44)$ & 11.47 & 88.53 & \\
\hline$(45-64)$ & 44.10 & 55.90 & \\
\hline$(65+)$ & 76.24 & 23.76 & \\
\hline \multicolumn{3}{|c|}{ Highest level of education attained based on the ISCED } & \multirow{4}{*}{$\begin{array}{l}\text { Cramer's V = 0.19912; } \\
\text { Lambda C|R = 0.0000; } \\
\text { Chi-squared (p-value) <0.0001; } \\
\text { Uncertainty Coeff. C|R }=0.0329\end{array}$} \\
\hline Primary & 48.68 & 51.32 & \\
\hline Secondary & 35.19 & 64.81 & \\
\hline Tertiary & 16.81 & 83.19 & \\
\hline \multicolumn{3}{|l|}{ Marital status } & \multirow{5}{*}{$\begin{array}{l}\text { Cramer's V = 0.3911; } \\
\text { Lambda C|R = 0.1594; } \\
\text { Chi-squared (p-value) <0.0001; } \\
\text { Uncertainty Coeff. C|R }=0.1241\end{array}$} \\
\hline Never married & 12.79 & 87.21 & \\
\hline Married & 36.58 & 63.42 & \\
\hline Widowed & 80.60 & 19.40 & \\
\hline Divorced & 44.77 & 55.23 & \\
\hline \multicolumn{3}{|l|}{ Basic activity status } & \multirow{5}{*}{$\begin{array}{l}\text { Cramer's V = 0.5160; } \\
\text { Lambda C|R = 0.3783; } \\
\text { Chi-squared (p-value) <0.0001; } \\
\text { Uncertainty Coeff. C|R }=0.2041\end{array}$} \\
\hline At work & 18.03 & 81.97 & \\
\hline Unemployed & 31.71 & 68.29 & \\
\hline In retirement or early retirement & 76.41 & 23.59 & \\
\hline Other inactive person & 22.09 & 77.91 & \\
\hline \multicolumn{3}{|l|}{ Equalised disposable income } & \multirow{6}{*}{$\begin{array}{l}\text { Cramer's V = 0.1656; } \\
\text { Lambda C|R = 0.0000; } \\
\text { Chi-squared (p-value) <0.0001; } \\
\text { Uncertainty Coeff. C|R }=0.0224\end{array}$} \\
\hline 1. quintile & 36.12 & 63.88 & \\
\hline 2. quintile & 42.59 & 57.41 & \\
\hline 3. quintile & 38.94 & 61.06 & \\
\hline 4. quintile & 32.45 & 67.55 & \\
\hline 5. quintile & 20.55 & 79.45 & \\
\hline
\end{tabular}




\section{Tab. 1: Self-perceived health according to sociodemographic characteristics of respondents - Part 2}

\begin{tabular}{|c|c|c|c|}
\hline \multirow[b]{2}{*}{ Explanatory variables } & \multicolumn{2}{|c|}{ SPH status } & \multirow{2}{*}{$\begin{array}{c}\text { Cramer's V; Lambda C|R; } \\
\text { Chi-squared ( } p \text {-value); } \\
\text { Uncertainty Coeff. C|R }\end{array}$} \\
\hline & $\begin{array}{c}0 \\
(\%)\end{array}$ & $\begin{array}{c}1 \\
(\%)\end{array}$ & \\
\hline \multicolumn{3}{|l|}{ Severely material deprivation } & \multirow{3}{*}{$\begin{array}{l}\text { Cramer's V = } 0.0876 ; \\
\text { Lambda C|R = 0.0000; } \\
\text { Chi-squared ( } p \text {-value) }<0.0001 ; \\
\text { Uncertainty Coeff. } C \mid R=0.0057\end{array}$} \\
\hline Not deprived & 32.33 & 67.67 & \\
\hline Deprived & 47.58 & 52.42 & \\
\hline \multicolumn{3}{|l|}{ NUTS 3} & \multirow{9}{*}{$\begin{array}{l}\text { Cramer's V }=0.0640 ; \\
\text { Lambda C|R = } 0.0000 ; \\
\text { Chi-squared ( } p \text {-value) }<0.0001 ; \\
\text { Uncertainty Coeff. } C \mid R=0.0032\end{array}$} \\
\hline Bratislava region & 27.23 & 72.77 & \\
\hline Trnava region & 33.01 & 66.99 & \\
\hline Trenčín region & 39.69 & 60.31 & \\
\hline Nitra region & 33.80 & 66.20 & \\
\hline Žilina region & 33.97 & 66.03 & \\
\hline Banská Bystrica region & 32.49 & 67.51 & \\
\hline Prešov region & 34.18 & 65.82 & \\
\hline Košice region & 33.98 & 66.02 & \\
\hline \multicolumn{3}{|l|}{ Degree of urbanization } & \multirow{4}{*}{$\begin{array}{l}\text { Cramer's V = 0.0615; } \\
\text { Lambda C|R = } 0.0000 ; \\
\text { Chi-squared ( } p \text {-value) }<0.0001 ; \\
\text { Uncertainty Coeff. } C \mid R=0.0030\end{array}$} \\
\hline Densely-populated area & 28.33 & 71.67 & \\
\hline Intermediate urbanized area & 34.46 & 65.54 & \\
\hline Thinly-populated area & 35.67 & 64.33 & \\
\hline
\end{tabular}

Source: based on Statistical Office of the Slovak Republic, EU SILC 2016, UDB 27/04/2017

Tab. 1 shows significant differences in selfperceived health in the Slovak Republic also by severe deprivation, NUTS 3 and degree of urbanization.

Tab. 2 shows the odds ratios (OR) for good self-perceived health status derived from binary logistic regression in association with the 26 health-risk indicators. To estimate the precision of the odds ratio $95 \%$ confidence intervals have been used. Because the gender difference in $\mathrm{SPH}$ is significant, this analysis was conducted separately for each sex.

In order to interpret the results of this analysis, the reference groups are chosen as female, age $65+$, in retirement or early retirement, primary level of education, divorced marital status, severely materially deprived, the $0-20 \%$ equivalised income quintile, Prešov region by NUTS 3 and thinly-populated area.

All selected variables were significantly associated with SPH $(p<0.05)$. Young persons, persons with higher educational attainment, economically active persons and persons with high income reported good SPH status. Have been found out that young age is associated with good SPH. Strong and significant predictors of good SPH status were age category $(16-24)\left(\mathrm{OR}_{(16-24 \text { vs. } 65+)}=2.323\right)$ and category (25-44) $\left(\mathrm{OR}_{(25-44 \text { vs. } 65+)}=1.629\right)$. There were differences between men and women $\left(\mathrm{OR}_{(16-24 \text { vs. } 65+)}=5.783\right.$ for men and $\mathrm{OR}_{(16-24 \text { vs. 65+) }}=1.533$ for women).

Working individual tended to rate their health better than person in retirement or early retirement and then other inactive person. The odds of the working respondent's selfassessment of his/her general health state is good (very good or good) is 1.739 times higher than if the person is in retirement or early retirement. There were differences between men and women. The odds of the working man is 2.171 times higher than if the working men in retirement or early retirement. The odds of the working women is only 1.505 times higher than if the women is in retirement or early retirement. If the person is other inactive, then the odds is about three times smaller than if the person is in retirement or early retirement. 
Tab. 2: Odds ratio estimates (Point estimate, 95\% Wald confidence limits) - Part 1

\begin{tabular}{|c|c|c|c|}
\hline \multicolumn{4}{|c|}{ Odds ratio estimates } \\
\hline \multirow[t]{2}{*}{ Variable } & \multicolumn{3}{|c|}{$\begin{array}{c}\text { Point estimate } \\
\text { 95\% Wald confidence limits }\end{array}$} \\
\hline & Total & Men & Women \\
\hline InAge & $\begin{array}{c}0.028 \\
0.018 ; 0.044\end{array}$ & $\begin{array}{c}0.039 \\
0.020 ; 0.074\end{array}$ & $\begin{array}{c}0.024 \\
0.013 ; 0.045\end{array}$ \\
\hline \multicolumn{4}{|l|}{ Age } \\
\hline$(16-24)$ & $\begin{array}{c}2.323 \\
1.331 ; 4.055\end{array}$ & $\begin{array}{c}5.783 \\
2.463 ; 13.578\end{array}$ & $\begin{array}{c}1.533 \\
0.722 ; 3.255\end{array}$ \\
\hline$(25-44)$ & $\begin{array}{c}1.629 \\
1.207 ; 2.199\end{array}$ & $\begin{array}{c}1.490 \\
0.950 ; 2.338\end{array}$ & $\begin{array}{c}1.668 \\
1.111 ; 2.503\end{array}$ \\
\hline$(45-64)$ & $\begin{array}{c}1.199 \\
1.008 ; 1.425\end{array}$ & $\begin{array}{c}1.098 \\
0.839 ; 1.435\end{array}$ & $\begin{array}{c}1.280 \\
1.018 ; 1.610\end{array}$ \\
\hline$(65+)$ & \multicolumn{3}{|c|}{ Reference category } \\
\hline \multicolumn{4}{|c|}{ Highest level of education attained based on the ISCED } \\
\hline Secondary & $\begin{array}{c}1.526 \\
1.312 ; 1.776\end{array}$ & $\begin{array}{c}1.297 \\
1.009 ; 1.669\end{array}$ & $\begin{array}{c}1.610 \\
1.328 ; 1.953\end{array}$ \\
\hline Tertiary & $\begin{array}{c}2.776 \\
2.298 ; 3.354\end{array}$ & $\begin{array}{c}2.306 \\
1.696 ; 3.135\end{array}$ & $\begin{array}{c}2.986 \\
2.339 ; 3.813\end{array}$ \\
\hline Primary & \multicolumn{3}{|c|}{ Reference category } \\
\hline \multicolumn{4}{|l|}{ Marital status } \\
\hline Never married & $\begin{array}{c}1.120 \\
0.916 ; 1.370\end{array}$ & $\begin{array}{c}1.085 \\
0.767 ; 1.535\end{array}$ & $\begin{array}{c}1.119 \\
0.860 ; 1.456\end{array}$ \\
\hline Married & $\begin{array}{c}1.298 \\
1.108 ; 1.521\end{array}$ & $\begin{array}{c}1.086 \\
0.808 ; 1.458\end{array}$ & $\begin{array}{c}1.367 \\
1.127 ; 1.658\end{array}$ \\
\hline Widowed & $\begin{array}{c}0.733 \\
0.585 ; 0.918\end{array}$ & $\begin{array}{c}0.701 \\
0.415 ; 1.182\end{array}$ & $\begin{array}{c}0.766 \\
0.592 ; 0.991\end{array}$ \\
\hline Divorced & \multicolumn{3}{|c|}{ Reference category } \\
\hline \multicolumn{4}{|l|}{ Basic activity status } \\
\hline At work & $\begin{array}{c}1.739 \\
1.479 ; 2.045\end{array}$ & $\begin{array}{c}2.171 \\
1.690 ; 2.788\end{array}$ & $\begin{array}{c}1.505 \\
1.213 ; 1.868\end{array}$ \\
\hline Unemployed & $\begin{array}{c}0.928 \\
0.723 ; 1.190\end{array}$ & $\begin{array}{c}1.107 \\
0.760 ; 1.613\end{array}$ & $\begin{array}{c}0.793 \\
0.565 ; 1.111\end{array}$ \\
\hline Other inactive person & $\begin{array}{c}0.312 \\
0.248 ; 0.392\end{array}$ & $\begin{array}{c}0.153 \\
0.101 ; 0.231\end{array}$ & $\begin{array}{c}0.395 \\
0.294 ; 0.531\end{array}$ \\
\hline $\begin{array}{l}\text { In retirement or early retirement or has } \\
\text { given up business }\end{array}$ & \multicolumn{3}{|c|}{ Reference category } \\
\hline \multicolumn{4}{|l|}{ Equalised disposable income } \\
\hline 2. quintile & $\begin{array}{c}1.043 \\
0.894 ; 1.216\end{array}$ & $\begin{array}{c}1.041 \\
0.820 ; 1.321\end{array}$ & $\begin{array}{c}1.059 \\
0.864 ; 1.298\end{array}$ \\
\hline 3. quintile & $\begin{array}{c}1.037 \\
0.888 ; 1.211\end{array}$ & $\begin{array}{c}1.046 \\
0.825 ; 1.326\end{array}$ & $\begin{array}{c}1.036 \\
0.841 ; 1.275\end{array}$ \\
\hline 4. quintile & $\begin{array}{c}1.021 \\
0.873 ; 1.195\end{array}$ & $\begin{array}{c}1.006 \\
0.793 ; 1.277\end{array}$ & $\begin{array}{c}1.048 \\
0.849 ; 1.294\end{array}$ \\
\hline
\end{tabular}




\begin{tabular}{|c|c|c|c|}
\hline \multicolumn{4}{|c|}{ Odds ratio estimates } \\
\hline \multirow[t]{2}{*}{ Variable } & \multicolumn{3}{|c|}{$\begin{array}{c}\text { Point estimate } \\
\text { 95\% Wald confidence limits }\end{array}$} \\
\hline & Total & Men & Women \\
\hline 5. quintile & $\begin{array}{c}1.579 \\
1.341 ; 1.859\end{array}$ & $\begin{array}{c}1.594 \\
1.245 ; 2.042\end{array}$ & $\begin{array}{c}1.581 \\
1.268 ; 1.972\end{array}$ \\
\hline 1. quintile & \multicolumn{3}{|c|}{ Reference category } \\
\hline \multicolumn{4}{|l|}{ Severely material deprivation } \\
\hline Not deprived & $\begin{array}{c}1.390 \\
1.167 ; 1.656\end{array}$ & $\begin{array}{c}1.317 \\
1.005 ; 1.726\end{array}$ & $\begin{array}{c}1.439 \\
1.141 ; 1.814\end{array}$ \\
\hline Deprived & \multicolumn{3}{|c|}{ Reference category } \\
\hline \multicolumn{4}{|l|}{ NUTS 3} \\
\hline Bratislava region & $\begin{array}{c}1.366 \\
1.127 ; 1.654\end{array}$ & $\begin{array}{c}1.399 \\
1.048 ; 1.868\end{array}$ & $\begin{array}{c}1.356 \\
1.047 ; 1.756\end{array}$ \\
\hline Trnava region & $\begin{array}{c}1.177 \\
0.981 ; 1.413\end{array}$ & $\begin{array}{c}1.278 \\
0.974 ; 1.677\end{array}$ & $\begin{array}{c}1.102 \\
0.860 ; 1.412\end{array}$ \\
\hline Trenčín region & $\begin{array}{c}0.761 \\
0.637 ; 0.908\end{array}$ & $\begin{array}{c}0.773 \\
0.595 ; 1.004\end{array}$ & $\begin{array}{c}0.752 \\
0.591 ; 0.959\end{array}$ \\
\hline Nitra region & $\begin{array}{c}1.143 \\
0.956 ; 1.366\end{array}$ & $\begin{array}{c}1.105 \\
0.846 ; 1.444\end{array}$ & $\begin{array}{c}1.185 \\
0.930 ; 1.509\end{array}$ \\
\hline Žilina region & $\begin{array}{c}0.975 \\
0.820 ; 1.159\end{array}$ & $\begin{array}{c}0.883 \\
0.683 ; 1.141\end{array}$ & $\begin{array}{c}1.056 \\
0.834 ; 1.336\end{array}$ \\
\hline Banská Bystrica region & $\begin{array}{c}1.273 \\
1.068 ; 1.517\end{array}$ & $\begin{array}{c}1.352 \\
1.040 ; 1.759\end{array}$ & $\begin{array}{c}1.221 \\
0.963 ; 1.549\end{array}$ \\
\hline Košice region & $\begin{array}{c}0.995 \\
0.877 ; 1.182\end{array}$ & $\begin{array}{c}0.969 \\
0.749 ; 1.253\end{array}$ & $\begin{array}{c}1.026 \\
0.812 ; 1.296\end{array}$ \\
\hline Prešov region & \multicolumn{3}{|c|}{ Reference category } \\
\hline \multicolumn{4}{|l|}{ Degree of urbanization } \\
\hline Densely-populated area & $\begin{array}{c}1.221 \\
1.068 ; 1.396\end{array}$ & $\begin{array}{c}1.160 \\
0.948 ; 1.420\end{array}$ & $\begin{array}{c}1.272 \\
1.062 ; 1.524\end{array}$ \\
\hline Intermediate urbanized area & $\begin{array}{c}0.968 \\
0.872 ; 1.075\end{array}$ & $\begin{array}{c}0.994 \\
0.851 ; 1.161\end{array}$ & $\begin{array}{c}0.952 \\
0.826 ; 1.098\end{array}$ \\
\hline Thinly-populated area & \multicolumn{3}{|c|}{ Reference category } \\
\hline
\end{tabular}

R-Square 0.3730; Max-rescaled R-Square 0.5104

Source: based on Statistical Office of the Slovak Republic, EU SILC 2016, UDB 27/04/2017

Family and partnership has an effect on the self-perception of health. The prevalence of self-reported good health was $87.21 \%$ in never married and $63.42 \%$ in married, whereas bad health was reported by $80.60 \%$ in widowed and $44.77 \%$ in divorced. When comparing married and divorced individuals, the odds of declaring good health is 1.298 times higher. The odds of the widowed respondent is $1 / 0.733=1.36$ times higher than if the person divorced. Have been found that higher equalized income was significantly associated with good $\mathrm{SPH}$ status $\left(\mathrm{OR}_{(5 . \text { quintile vs. 1. quintile) }}=0.579, \mathrm{OR}_{(2 \text {. quintile vs. }}\right.$ 1. quintile) $=1.043)$.

\section{Conclusions}

Several studies have analysed the association between health and socio-economic status, in 
particular, health and education, health and income or wealth, health and unemployment, as detailed in Chapter 1. A positive relationship between health and socio-economic status is widely documented across many societies and periods. Only a small part of studies is devoted to socio-economic differences in self-assessed health status in eastern European countries. If so, most analyses end with the statement that the eastern European countries are those where individuals report the poorest health.

The results of the descriptive analysis in Chapter 3 show that the differences in 'very good' or 'good' self-perceived health according to some variants of socio-economic determinants between old and new members of the EU-28 were not very large in 2018. This can be seen in the 'Tertiary education' variant in Fig. 5 , in the variant '5th income quintile group' by income in Fig. 6 and in the labour status variant 'Employees' in Fig. 7. Unfortunately, the prevalence of assessment self-perceived health as 'very good' or 'good' in the former socialist countries is significantly lower than in the western and Nordic countries in the case of primary education, 1st income quintile and in case of retired persons.

Considering not favourable assessment of health status of the Slovak population, mainly by the indicators of the incidence and mortality for cardiovascular and oncological diseases (Wilkins et al., 2017), the results of self-perceived health compared to other EU Member States is surprisingly good. Selfperceived health of persons aged 16 and over, by gender in EU-28 (Fig. 1) and in the Slovak Republic (Fig. 9) is comparable. Good self-perceived health status in the Slovak Republic (SR) confirmed also comparisons by different socio-economics and demographics determinants across the countries of EU-28 in Fig. 2, Fig. 3 and Figs. 5-8. It can be stated that self-perceived health status in SR is very good, especially in comparison within the new EU Member States. Within the EU-28 countries and within the SR too, there are clear differences in self-perceived health according to gender, age, level of education, income, labour status and degree of urbanization.

The development of the proportion of persons aged 16 and over with 'very good' or 'good' self-perceived health in the Slovak Republic is also positive in comparison with the other seven European countries in the period
2005-2018. The differences in recent years between the Slovak Republic and neighboring Austria is only about $5 \%$ (Fig. 3). Within Slovakia, the assessment of self-perceived health as very good or good differs considerably in primary and tertiary education (Fig. 5), as well as between employees and retired persons (Fig. 7).

Logistic regression, applied to individual data of respondents included in EU SILC 2016 sample in the Slovak Republic, provides more accurate information about the impact of different demographics and socio-economic determinants on self-perceived health.

We have analysed the subjective perception of health variable, which is part of the Minimum European Health Module (MEHM). The respondents answered the question: "How do you assess your health condition overall?", by choosing one of these answers: very good, good, satisfactory, bad and very bad. From the analysed sample, $3.016(21.51 \%)$ of the population perceive their health as 'very good', $5.886(41.98 \%)$ perceive it as 'good', 3.168 $(22.59 \%)$ perceive it as 'satisfactory', 1.497 (10.68\%) as 'bad' and 454 (3.24\%) expressed that they perceive their health as 'very bad'. For the purposes of further analyses, the first two categories have been merged into a single category - 'good' (quantified as 1) and the other three were also merged into a single category - 'bad' (quantified as 0). The purpose of this modification is to prevent possible issues in modelling, which are related to the low quantity of the 'very bad' category. Given the nature of this created variable, the paper uses the binary logistic regression model to predict the category of good health assessment. Using the stepwise selection method, we have selected nine variables statistically significantly affecting good perception of health.

The results of the bivariate analysis showed that the variable Age (Cramer's $V=0.5275$ ) has the most substantial influence on self-perceived health. Basic activity status (Cramer's V $=0.5160$ ), Marital status (Cramer's $V=0.5160$ ), and Highest level of education (Cramer's $V=0.3911$ ) attained based on the ISCED (Cramer's $V=0.1991)$. The results of logistic regression models also showed their differentiating effect on the chance to evaluate their health as good. These were created separately for both genders. The most significant differences were found when 
comparing age categories 16-24 and 65+ $\left(\mathrm{OR}_{(16-24 \text { vs. 65+) }}=2.323\right)$. There were differences between men and women $\left(\mathrm{OR}_{(16-24 \text { vs. } 65+)}=5.783\right.$ for men and $\mathrm{OR}_{(16-24 \text { vs. } 65+)}=1.533$ for women). Male respondents, who have completed tertiary education, are 2.776 times more likely to rate their health as good compared to those who have completed only primary education. For women, this ratio is even higher $\left(\mathrm{OR}_{\text {(tertiary vs. }}\right.$ primary) $=2.986$ ). If the respondent is a worker, the chance that he/she will rate his/her health as good is 1.739 times higher than for pensioners, while this chance is even higher for men $(O R=2.171)$. When comparing other inactive persons and pensioners, the odds ratio for men is $6.5359(1 / 0.153)$ and for women 2.5316 (1/0.395). An interesting conclusion is the finding that the differentiating effect on health self-assessment did not manifest itself in the categorized variable Equalized disposable income. A statistically significant difference was confirmed only when comparing the chances of evaluating their health as good for respondents with income from the fifth quintile if we compare them with those whose income is from the first quintile $\left(\mathrm{OR}_{(5 \text {. quintile vs. 1. quintile) }}=1.579\right)$ without gender difference.

From the results of the analysis in this article, it follows that self-perceived health is not confirmed that the objective of reducing health inequalities between and within EU Member States (European Union, 2010, 2013; United Nations, 2015) is successfully implementing. However, they confirm the fact that demographics determinants (gender, age) and socio-economic determinants (education, income, labour status, degree of urbanization) have a significant impact on the feeling of good health of the inhabitants in the EU-28 countries, as well as of the inhabitants of Slovakia. This leads to the conclusion that health inequalities must be implemented by reducing socioeconomic inequalities (in income, in labour status, in education) and by increasing the quality of health care and quality of life of older people.

\section{References}

Allison, P. D. (2012). Logistic Regression Using SAS: Theory and Application (2nd ed.). Cary, NC: SAS Institute.

Alvarez-Galvez, J., Rodero-Cosano, M. L., Motrico, E., Salinas-Perez, J. A., GarciaAlonso, C., \& Salvador-Carulla, L. (2013). The impact of socio-economic status on self-rated health: study of 29 countries using European social surveys (2002-2008). International Journal of Environmental Research and Public Health, 10(3), 747-761. https://doi.org/10.3390/ ijerph10030747

Alvarez-Galvez, J., Rodero-Cosano, M. L., García-Alonso, C., \& Salvador-Carulla, L. (2014). Changes in socioeconomic determinants of health: comparing the effect of social and economic indicators through European welfare state regimes. Journal of Public Health, 22, 305-311. https://doi.org/10.1007/s10389-0140623-x

Alvarez-Galvez, J. (2016). Discovering complex interrelationships between socioeconomic status and health in Europe: A case study applying Bayesian Networks. Social Science Research, 56, 133-143. https://doi.org/10.1016/j.ssresearch.2015.12.011

Bambra, C., Gibson, M., Sowden, A., Wright, K., Whitehead, M., \& Petticrew, M. (2010). Tackling the Wider Social Determinants of Health and Health Inequalities: Evidence from Systematic Reviews. Journal of Epidemiology and Community Health, 64(4), 284-291. https://doi.org/10.1136/jech.2008.082743

Bound, J. (1991). Self-reported versus objective measures of health in retirement models. Journal of Human Resources, 26(1), 106-138. https://doi.org/10.2307/145718

Böckerman, P., \& Ilmakunnas, P. (2009). Unemployment and Self-Assessed Health: Evidence from Panel Data. Health Economics, 18(2), 161-179. https://doi.org/10.1002/ hec. 1361

Croezen, S., Burdorf, A., \& van Lenthe, F. J. (2016). Self-perceived health in older Europeans: Does the choice of survey matter? The European Journal of Public Health, 26(4), 686-692. https://doi.org/10.1093/eurpub/ckw017

Department of Health and Social Security. (1980). Inequalities in Health (Report of a Working Group). London: DHSS.

Eikemo, T. A., Huisman, M., Bambra, C., \& Kunst, A. E. (2008). Health inequalities according to educational level in different welfare regimes: A comparison of 23 European countries. Sociology of Health \& Illness, 30(4), 565-582. https://doi.org/10.1111/j.14679566.2007.01073.x

European Commission. (2007). Together for Health: A Strategic Approach for the EU 20082013(White paper). Brussels: EC. Retrieved May 
9, 2019, from https://eur-lex.europa.eu/legalcontent/EN/ALL/?uri=CELEX:52007DC0630

European Commission. (2013). Investing in Health (Comission Staff Working Document). Brussels: EC. Retrieved May 9, 2019, from https://eur-lex.europa.eu/legal-content/EN/TXT/ PDF/?uri=CELEX:52013SC0043\&from=EN

European Commission. (2016). Joint Report on Health Care and Long-Term Care Systems and Fiscal Sustainability. Luxembourg: Publications Office of the European Union. Retrieved May 9, 2019, from https://ec.europa.eu/info/sites/info/ files/file_import/ip037_vol1_en_2.pdf

European Commission.

(2017).

Methodological guidelines and descriptions of EU-SILC, target variables, 2017 operation (Version May 2017). Retrieved May 9, 2019, from https://circabc.europa.eu/sd/a/6bc65c53-614845da-bfc7-39e43e0d1438/DOCSILC065\%20 operation\%202017-\%2005-09-16.pdf

European Union. (2010). Reducing health inequalities in the European Union. Luxembourg: Publications Office of the European Union. https://op.europa.eu/publication/doi/10.2767/96086

European Union. (2013). Health inequalities in the EU (Final report of a consortium). Luxembourg:Publications Office of the European Union. https://op.europa.eu/publication/doi/10. 2772/34426

Eurostat. (2010). Analysing the socioeconomic determinants of health in Europe: New evidence from EU-SILC (Methodologies and Working papers). Luxembourg: Publications Office of the European Union. https://doi.org/10.2785/5478

Eurostat Statistics Explained. (2020). Health in the European Union - facts and figures. Luxembourg: Publications Office of the European Union. Retrieved March 5, 2020, from https://ec.europa.eu/eurostat/statisticsexplained/index.php?title=Health_in_the European_Union_\%E2\%80\%93_facts_and_ figures\#1._Health_status

Eurostat Statistics Explained. (2020). Self-perceived health statistics. Luxembourg: Publications Office of the European Union. Retrieved March 5, 2020, from https://ec.europa. eu/eurostat/statistics-explained/index.php/Selfperceived_health_statistics\#Self-perceived_ health

GBD 2015 Risk Factors Collaborators. (2016). Global, Regional, and National Comparative Risk Assessment of 79 Behavioural, Environmental and Occupational, and Metabolic Risks or Clusters of Risks, 1990-2015: A Systematic Analysis for the Global Burden of Disease Study 2015. The Lancet, 388(10053), 1659-1724. https://doi. org/10.1016/S0140-6736(16)31679-8

Hernández-Quevedo, C., Masseria, C., \& Mossialos, E. (2010). Analyzing the socioeconomic determinants of health in Europe: new evidence from EU-SILC. Luxembourg: Publications Office of the European Union. https://doi.org/10.2785/5478

Hosmer, D. W., \& Lemeshow, S. (2004). Applied Logistic Regression. Hoboken, $\mathrm{NJ}$ : John Wiley \& Sons.

Hunt, S. M., McKenna, S. P., McEwen, J., Backett, E. M., Williams, J., \& Papp, E. (1980). A quantitative approach to perceived health status: A validation study. Journal of Epidemiology and Community Health, 34(4), 281-286. https://doi.org/10.1136/jech.34.4.281

Johansson, E., Böckerman, P., \& Lundqvist, A. (2020). Self-reported health versus biomarkers: does unemployment lead to worse health? Public Health, 179, 127-134. https://doi.org/10.1016/j.puhe.2019.10.005

Kaleta, D., Makowiec-Dabrowska, T., \& Jegier, A. (2008). Job status and self-perceived health. International Journal of Working Medicine and Health, 21(3), 227-236.

Kaleta, D., Polańska, K., DziankowskaZaborszczyk, E., Hanke, W., \& Drygas, W. (2009). Factors Influencing Self-perception of Health Status. Central European Journal of Public Health, 17(3), 122-127. https://doi. org/10.21101/cejph.b0017

Karasová, K., Baláž, V., \& Poláčková, Z. (2019). Efficiency of the Active Labour Market Policies: Evidence from the Slovak Republic. Ekonomický časopis, 67(1), 11-32.

Manderbacka, K., Lundberg, O., \& Martkainen, P. (1999). Do risk factors and health behaviours contribute to self-ratings of health? Social Science \& Medicine, 48(12), 1713-1720. https://doi.org/10.1016/S02779536(99)00068-4

Marmot, M., Goldblatt, P., \& Allen, J. (2010). Fair Society, Healthy Lives (Report 2/2010). London: Institute of Health Equity. Retrieved August 5, 2020, from http://www. marmotreview.org/AssetLibrary/pdfs/Reports/ FairSocietyHealthyLives.pdf

Marmot, M., \& Wilkinson, R. (2006). Social Determinants of Health (2nd ed.). Oxford: Oxford University Press. 
Nummela, O. P., Sulander, T. T., Heinonen, H. S., \& Uutela, A. K. (2007). Self-rated health and indicators of SES among the ageing in three types of communities. Scandinavian Journal of Public Health, 35(1), 39-47. https://doi.org/10.1080/14034940600813206

OECD. (2015). Health Inequalities. Paris: OECD Publishing. Retrieved March 9, 2020, from http://www.oecd.org/health/inequalities-inhealth.htm

OECD/EU. (2018). Health at a Glance: State of Health in the EU Cycle. Paris: OECD Publishing/Brussels: EU. Retrieved January 19, 2020, from https://doi.org/10.1787/health_ glance_eur-2018-en

OECD. (2019). Health at a Glance 2019: OECD Indicators. Paris: OECD Publishing. https://doi.org/10.1787/4dd50c09-en

Olsen, K. M., \& Dahl, S.-Å. (2007). Health differences between European countries. Social Science and Medicine, 64(8), 1665-1678. https://doi.org/10.1016/j. socscimed.2006.11.031

Pacáková, V., \& Kopecká, L. (2018a). Inequalities in Health Status Depending on Socioeconomic Situation in the European Countries. E\&M Economics and Management, 21(2), 4-20. https://doi.org/10.15240/tul/001/2018-2-001

Pacáková, V., \& Kopecká, L. (2018b). Comparing inequalities in health outcomes in European countries. Journal of International Studies, 11(4), 215-227. https://doi. org/10.14254/2071-8330.2018/11-4/15

Pacáková, V., \& Jindrová, P. (2019). Determinants of Health Inequalities in European Countries. WSEAS Transactions on Business and Economics, 16, 25-38.

Pärna, K., \& Ringmets, I. (2010). Comparison of socioeconomic differences in self-perceived health in Estonia and Finland. Scandinavian Journal of Public Health, 38(2), 129-134. https://doi.org/10.1177/1403494809357259

Pickett, K. E., \& Wilkinson, R. G. (2015). Income Inequality and Health: A Causal Review. Social Science \& Medicine,
128, 316-326. https://doi.org/10.1016/j. socscimed.2014.12.031

Prokop, V., Odeil, S. A., \& Stejskal, J. (2018). Propellants of University-IndustryGovernment Synergy: Comparative Study of Czech and Slovak Manufacturing Industries. Ekonomický časopis, 66(10), 987-1001.

Robards, J., Evandrou, M., Falkingham, J., \& Vlachantoni, A. (2012). Marital status, health and mortality. Maturitas, 73(4), 295-299. https://doi.org/10.1016/j.maturitas.2012.08.007

Shields, M., \& Shooshtari, S. (2001). Determinants of self-perceived health. Health Reports, 13(1), 35-52.

Stankovičová, I., \& Vojtková, M. (2007). Viacrozmerné štatistické metódy s aplikáciami. Bratislava: lura Edition.

Statistical Office of the Slovak Republic. (2017). EU SILC 2016. Retrieved April 4, 2017.

Szeles, M. R. (2018). Comparative Examination of Self-Perceived Health and Other Measures of the Quality of Life Across the EU-27. Social Indicators Research, 137(1), 391-411. https://doi.org/10.1007/s11205-017$1597-1$

United Nations. (2015). Transforming our world: the 2030 Agenda for Sustainable Development (Resolution adopted by the General Assembly on 25 September 2015). Retrieved March 8, 2020, from https://www. un.org/ga/search/view_doc.asp?symbol=A/ RES/70/1\&Lang $=E$

WHO/World Health Organization. (1946). Constitution of WHO: principles. Retrieved March 12, 2020, from https://www.who.int/ about/mission/en/

Wilkins, E., Wilson, L., Wickramasinghe, K., Bhatnagar, P., Leal, J., Luengo-Fernandez, R., Burns, R., Rayner, M., \& Townsend, N. (2017). European Cardiovascular Disease Statistics 2017. Brussels: European Heart Network.

Wilkinson, R. G., \& Pickett, K. (2009). The Spirit Level: Why More Equal Societies Almost Always Do Better. London: Allen Lane. 